\title{
Cytotoxic and Antimicrobial Compounds from the Marine-Derived Fungus, Penicillium Species
}

\author{
Diaa T. A. Youssef ${ }^{1, *(1)}$ and Abdulrahman M. Alahdal ${ }^{2}$ \\ 1 Department of Natural Products, Faculty of Pharmacy, King Abdulaziz University, Jeddah 21589, \\ Saudi Arabia \\ 2 Department of Clinical Pharmacy, Faculty of Pharmacy, King Abdulaziz University, Jeddah 21589, \\ Saudi Arabia; aalahdal2@hotmail.com \\ * Correspondence: dyoussef@kau.edu.sa or diaa22@yahoo.com; Tel.: +966-548-535-34
}

Received: 7 January 2018; Accepted: 6 February 2018; Published: 12 February 2018

\begin{abstract}
The organic extract of liquid cultures of the marine-derived Penicillium sp. was investigated. Fractionation of the extracts of the fungus led to the purification and identification of two new compounds, penicillatides A (1) and B (2), together with the previously reported cyclo(R-Pro-S-Phe) (3) and cyclo(R-Pro- $R$-Phe) (4). The structures of compounds 1-4 were assigned by extensive interpretation of their NMR and high-resolution mass spectrometry (HRMS). The antiproliferative and cytotoxic activities of the compounds against three human cancer cell lines as well as their antimicrobial activity against several pathogens were evaluated. Compounds $\mathbf{2}-\mathbf{4}$ displayed variable cytotoxic and antimicrobial activities.
\end{abstract}

Keywords: marine Penicillium sp.; 2,5-diketopiperazines; cytotoxic and antimicrobial activities

\section{Introduction}

Members of the genus Penicillium are among the most investigated fungi by natural products chemists and are considered a major source for drug discovery. Prominent fungal-derived drugs include the antibiotic penicillin, which was obtained from Penicillium chrysogenum, and the antifungal griseofulvin from Penicillium griseofulvum. Nowadays, the genus Penicillium still represents a major producer of secondary metabolites with diverse bioactivities, as reported in many recent reviews [1-5].

In the last decade, a significantly increased interest in secondary metabolites from marine microbes has been reported [2]. 2,5-Diketopiperazines (2,5-DKPs) are obtained from different organisms, including marine microbes. They represent an important group of cyclic dipeptides with diverse structures and significant biological activities [2]. Since the number of reported compounds with significant biological properties is increasing, several reviews covering the structural determinations, biological activities, and proposed biosynthetic pathways of this class of compounds have been reported [6-8]. Consequently, marine fungi appear to be a promising source of these interesting dipeptides. Several members of the 2,5-DKP class displayed cytotoxic, anti-inflammatory, and antimicrobial activities [9-12].

Our growing interest in identifying secondary metabolites from marine microbes resulted in the identification of several compounds with different bioactivities [13-17]. The organic extract of the fungus Penicillium sp. gave two new compounds, named penicillatides A and B (1 and $\mathbf{2})$, together with cyclo(D-Pro-L-Phe) \{cyclo(R-Pro-S-Phe) $\}$ (3) [18] and cyclo(R-Pro- $R$-Phe) (4) [19] (Figure 1). Structural determinations of the compounds were supported by interpretation of their spectroscopic data as well as comparison of available NMR data in the literature. In this paper, the structural determinations and the cytotoxic and antimicrobial activities of the compounds are reported. 
<smiles>CC(C)C[C@H](NC=O)C(=O)N1CCCC1=O</smiles>

1<smiles>O=C1N[C@H](Cc2ccccc2)C(=O)N2CCC[C@H]12</smiles><smiles>O=C1N[C@](O)(Cc2ccccc2)C(=O)N2[CH]CCCN12</smiles>

2<smiles>O=C1N[C@H](Cc2ccccc2)C(=O)N2CCC[C@H]12</smiles>

Figure 1. Chemical structures of compounds 1-4.

\section{Results and Discussion}

\subsection{Structure Elucidation of Compounds 1-4}

The high-resolution electrospray ionization mass spectrometry (HRESIMS) and NMR spectra (Figures S1-S4) of compound 1 (Figure 1) support the molecular formula of $\mathrm{C}_{11} \mathrm{H}_{18} \mathrm{~N}_{2} \mathrm{O}_{3}$. The ${ }^{13} \mathrm{C}-\mathrm{NMR}$ (Figure S2) spectrum of 1 (Figure S2) displayed signals for 11 carbons, including two methyls, four methylenes, two aliphatic methines, one aldehydic methine, and two quaternary amidic carbonyls (Table 1). Tracing of the ${ }^{1} \mathrm{H}-{ }^{1} \mathrm{H}$ couplings in the COSY spectrum (Figure S3) allowed the assignment of two structural subunits in 1: $N$-formylleucine (subunit A) and 2-oxopyrrolidine (subunit B) moieties (Figure 1 and Table 1 ). The first ${ }^{1} \mathrm{H}-{ }^{1} \mathrm{H}$ COSY coupling system led to the assignment of the $N$-formyl-leucine moiety as established from the multiplicity-edited HSQC spectral data (Figure S4) at $\delta_{\mathrm{H} / \mathrm{C}} 6.10(\mathrm{NH}), 173.7$ (qC, C-1), 5.81/49.9 (CH, H-2/C-2), 1.62, 1.42/41.5 ( $\left.\mathrm{CH}_{2}, \mathrm{H}_{2}-3 / \mathrm{C}-3\right)$, 1.74/25.0 (CH, H-4/C-4), 1.05/21.0 ( $\left.\mathrm{CH}_{3}, \mathrm{H}_{3}-5 / \mathrm{C}-5\right), 0.92 / 23.5\left(\mathrm{CH}_{3}, \mathrm{H}_{3}-6 / \mathrm{C}-6\right)$, and 8.21/160.6 (CH, $\mathrm{H}-11 / \mathrm{C}-11$ ) (Table 1). The ${ }^{1} \mathrm{H} /{ }^{13} \mathrm{C}$ chemical shift at $\delta_{\mathrm{H} / \mathrm{C}} 8.21 / 160.6$ is typical for an $N$-formyl moiety and in agreement with reported values [20]. The placement of the $N$-formyl moiety was supported by HMBC of H-2/C-11, H-11/C-2 as well as NOESY correlations of NH/H-2 and NH/H-11 (Figure 2). Further HMBC correlations (Figure S5) within the leucine moiety are shown in Table 1 and Figure 2. The second coupling system allowed the assignment of the 2-oxopyrrolidine subunit based on the continuous ${ }^{1} \mathrm{H}-{ }^{1} \mathrm{H}$ COSY coupling system of $\mathrm{H}_{2}-8 / \mathrm{H}_{2}-9 / \mathrm{H}_{2}-10$ and the ${ }^{1} \mathrm{H} /{ }^{13} \mathrm{C}$ NMR signals at $\delta_{\mathrm{H} / \mathrm{C}} 174.8$ (qC, C-7), 2.64, 2.61/33.4 ( $\left.\mathrm{CH}_{2}, \mathrm{H}_{2}-8 / \mathrm{C}-8\right)$, 2.09/17.3 $\left(\mathrm{CH}_{2}, \mathrm{H}_{2}-9 / \mathrm{C}-9\right)$, and 3.88, 3.77/45.6 $\left(\mathrm{CH}_{2}, \mathrm{H}_{2}-10 / \mathrm{C}-10\right)$. The HMBC correlations of $\mathrm{H}_{2}-8 / \mathrm{C}-7, \mathrm{H}_{2}-9 / \mathrm{C}-7$, and $\mathrm{H}_{2}-10 / \mathrm{C}-7$ supported the assignment of subunit B (Figure 2). Finally, the connection between the two subunits of $\mathbf{1}$ at $\mathrm{C}-1$ and the amidic nitrogen of the 2-oxopyrrolidine moiety was secured from the HMBC correlation from $\mathrm{H}_{2}-10$ to $\mathrm{C}-1$ (Figure 2), supporting the assignment of $\mathbf{1}$ as $\mathrm{N}$-( $\mathrm{N}$-formylleucyl)-2-oxopyrrolidine.

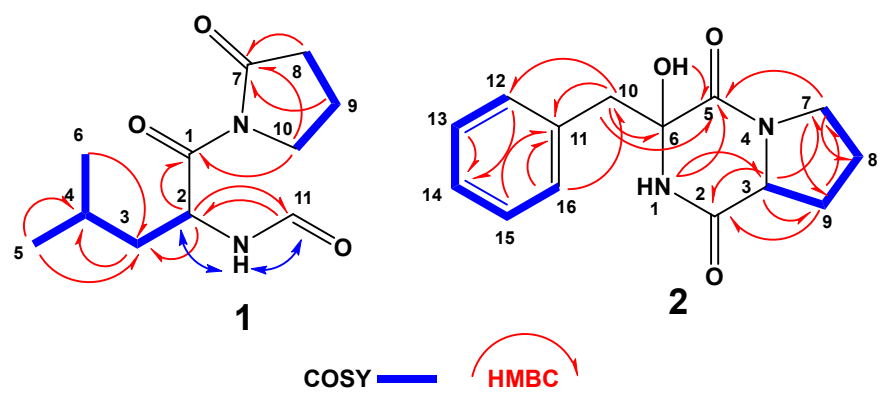

Figure 2. Key COSY and HMBC correlations of $\mathbf{1}$ and 2. 
Table 1. NMR data of compound $1\left(\mathrm{CDCl}_{3}, 850\right.$ and $\left.213 \mathrm{MHz}\right)$.

\begin{tabular}{ccccc}
\hline No. & $\boldsymbol{\delta}_{\mathbf{C}}$ (mult.) & $\boldsymbol{\delta}_{\mathbf{H}}$ (mult., $\boldsymbol{J}(\mathbf{H z}) \mathbf{H}$ & HMBC & NOESY \\
\hline $\mathbf{1}$ & $173.7, \mathrm{qC}$ & & $\mathrm{H}-2, \mathrm{H}_{2}-10$ & \\
$\mathbf{2}$ & $49.9, \mathrm{CH}$ & $5.81(\mathrm{dt}, 11.5,3.0)$ & $\mathrm{H}-11$ & $\mathrm{NH}$ \\
$\mathbf{3}$ & $41.5, \mathrm{CH}_{2}$ & $1.62(\mathrm{~m}), 1.42(\mathrm{~m})$ & $\mathrm{H}-2, \mathrm{H}_{3}-5, \mathrm{H}_{3}-6$ & \\
$\mathbf{4}$ & $25.0, \mathrm{CH}$ & $1.74(\mathrm{~m})$ & $\mathrm{H}_{3}-5, \mathrm{H}_{3}-6$ & \\
$\mathbf{5}$ & $21.0, \mathrm{CH}_{3}$ & $1.05(\mathrm{~d}, 6.5)$ & $\mathrm{H}_{3}-6$ & \\
$\mathbf{6}$ & $23.5, \mathrm{CH}_{3}$ & $0.92(\mathrm{~d}, 6.5)$ & $\mathrm{H}_{3}-5$ & \\
$\mathbf{7}$ & $174.8, \mathrm{qC}$ & & $\mathrm{H}_{2}-8, \mathrm{H}_{2}-9, \mathrm{H}_{2}-10$ & \\
$\mathbf{8}$ & $33.4, \mathrm{CH}_{2}$ & $2.64(\mathrm{dd}, 9.5,1.5)$ & $\mathrm{H}_{2}-9, \mathrm{H}_{2}-10$ & \\
$\mathbf{9}$ & $17.3, \mathrm{CH}_{2}$ & $2.61(\mathrm{dd}, 9.5,7.0)$ & $\mathrm{H}_{2}-7, \mathrm{H}_{2}-8$ & \\
$\mathbf{1 0}$ & $45.6, \mathrm{CH}_{2}$ & $3.83(\mathrm{~m}), 3.77(\mathrm{~m})$ & $\mathrm{H}_{2}-8, \mathrm{H}_{2}-9$ & \\
$\mathbf{1 1}$ & $160.6, \mathrm{CH}$ & $8.21(\mathrm{~s})$ & $\mathrm{H}-2$ & $\mathrm{NH}$ \\
$\mathbf{N H}$ & & $6.10(\mathrm{brs})$ & & $\mathrm{H}-2, \mathrm{H}-11$ \\
\hline
\end{tabular}

The absolute configuration of C-2 of the leucine residue was determined by Marfey's method (Scheme 1) [21]. HPLC analysis of the derivative of 1-fluoro-2,4-dinitrophenyl-5-L-alanine amide (FDAA, Marfey's reagent) with the hydrolytic product of $\mathbf{1}$ gave the same retention time as the derivative prepared from an authentic L-leucine, and therefore the L-configuration was assigned to the leucine residue. Thus, compound 1 was assigned as (S)- $N$-(4-methyl-1-oxo-1-(2-oxopyrrolidin1-yl)pentan-2-yl)formamide. The name penicillatide A was given to 1 , and it is reported here as a new natural compound.

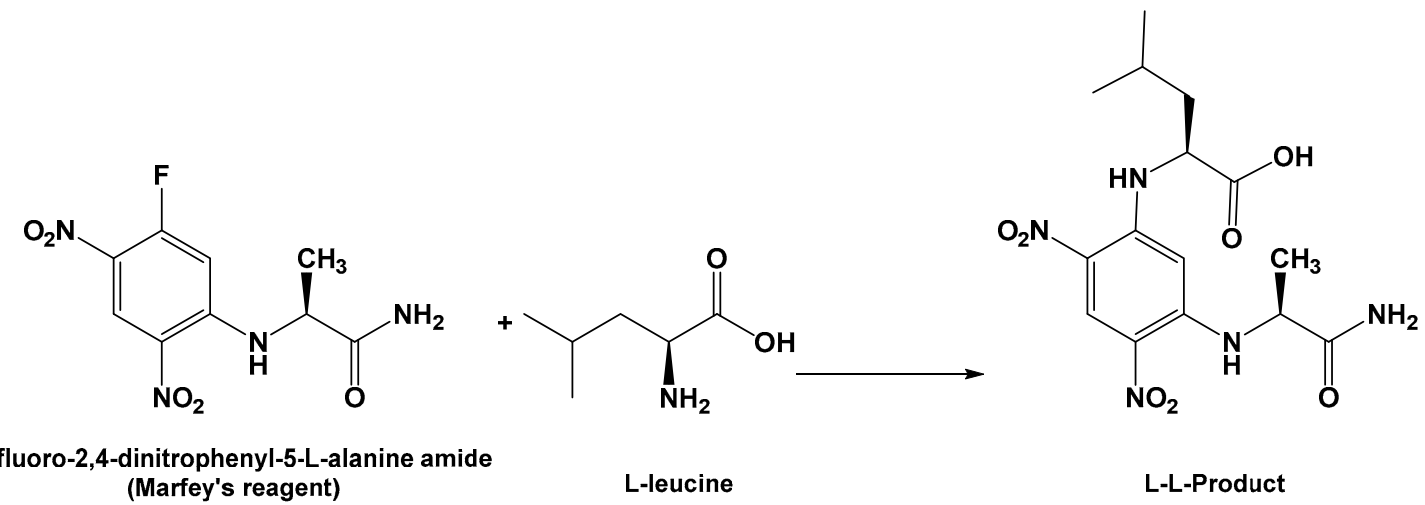

Scheme 1. Reaction of 1-fluoro-2,4-dinitrophenyl-5-L-alanine amide (FDAA) with the hydrolytic product of compound $\mathbf{1}$ (L-leucine).

Compound 2 (Figure 1) exhibited a molecular formula of $\mathrm{C}_{14} \mathrm{H}_{16} \mathrm{~N}_{2} \mathrm{O}_{3}$ as established by HRESIMS. The ${ }^{1} \mathrm{H} /{ }^{13} \mathrm{C}$ NMR signals (Figures $\mathrm{S} 6$ and S7, Table 2) at $\delta_{\mathrm{H} / \mathrm{C}} 6.13(1 \mathrm{H}$, brs, NH-1), 166.9 (qC, C-2), 2.85/59.6 (CH, H-3/C-3), and 166.1 (qC, C-5) suggested a diketopiperazine moiety as part of a cyclic dipeptide skeleton. The NMR data of compound 2 (Table 2) are very close to those of 3 . However, compound 2 displayed a signal for an oxygenated quaternary carbon at $\delta_{\mathrm{C}} 83.4$ and ${ }^{1} \mathrm{H}$ singlet at $\delta_{\mathrm{H}} 4.36(1 \mathrm{H}, \mathrm{OH})$ instead of the methine of $\mathrm{H}-6 / \mathrm{C}-6$ at $\delta_{\mathrm{H} / \mathrm{C}} 4.20 / 59.1$ in 3, suggesting the presence of a hydroxyl moiety at C-6 in 2. The placement of the $\mathrm{OH}$ at $\mathrm{C}-6$ was supported by HMBC correlations of $\mathrm{H}_{2}-10 / \mathrm{C}-6, \mathrm{H}_{2}-10 / \mathrm{C}-5$, and $\mathrm{OH} / \mathrm{C}-5$ (Figure 2 and Table 2). Furthermore, the COSY (Figure S8), HSQC (Figure S9) and HMBC experiments (Figure S10) supported the assignment of the structure of 2 as cyclo(Pro-2-OH-Phe) (Table 2 and Figure 2). The absolute configuration of C-3 of the proline residue was determined by Marfey's method [21]. HPLC analysis of the FDAA derivative of the hydrolytic product of $\mathbf{2}$ gave the same retention time as the derivative prepared from an authentic ( $\mathrm{L}$ )-proline, and therefore the $\mathrm{L}$-configuration was assigned to the proline residue 
(Scheme 2). The absolute configuration at C-6 of the phenylalanine residue was not determined by Marfey's method, because the hydroxyphenylalanine residue decomposed under acidic conditions. The relative configuration at C- 6 was established by comparing the chemical shift values of C-6 and $\mathrm{H}_{2}-10 / \mathrm{C}-10$ with a similar compound containing the $\alpha$-hydroxylated phenylalanine moiety, namely (3R,6S)-3-benzyl-3-hydroxy-1,4-dimethyl-6-((4-nitro-1H-indol-3-yl)methyl)piperazine-2,5-dione [22]. The $\delta_{\mathrm{H} / \mathrm{C}}$ of $3.14,3.05 / 47.8\left(\mathrm{H}_{2}-10 / \mathrm{C}-10\right)$, and 83.4 (C-6) in 2 were very close to the values in the literature [22], supporting the configuration of $\mathrm{OH}$ at $\mathrm{C}-6$, as shown in Figure 1. Furthermore, the configuration of the $\mathrm{OH}$ at $\mathrm{C}-6$ in $\mathbf{2}$ was also confirmed by the NOESY experiment, in which a strong correlation between $\mathrm{H}-3\left(\delta_{\mathrm{H}} 2.85\right)$ and $6-\mathrm{OH}\left(\delta_{\mathrm{H}} 4.36\right)$ was observed (Figure 3$)$. Further studies are needed to determine the absolute configuration at C-6 in 2 . Thus, the relative configuration at C-6 was assigned as $R^{*}$. Accordingly, compound 2 was assigned as (3R*,8aS)-3-benzyl-3hydroxyhexahydropyrrolo[1,2-a]pyrazine-1,4-dione. The name penicillatide B was given to compound 2, and it is reported here as a new natural product.

Table 2. NMR data of compound $2\left(\mathrm{CDCl}_{3}, 600\right.$ and $\left.150 \mathrm{MHz}\right)$.

\begin{tabular}{|c|c|c|c|}
\hline No. & $\delta_{C}$ (mult.) & $\delta_{H}$ (mult., $\left.J(\mathrm{~Hz})\right)$ & НМВС \\
\hline $1(\mathrm{NH})$ & & 6.13 (brs) & \\
\hline 2 & $166.9, \mathrm{qC}$ & & $\mathrm{H}-1, \mathrm{H}-3, \mathrm{H}_{2}-9$ \\
\hline 3 & $59.6, \mathrm{CH}$ & $2.85(\mathrm{dd}, 10.2,6.8)$ & $\mathrm{H}-1, \mathrm{H}_{2}-8, \mathrm{H}_{2}-9$ \\
\hline 5 & 166.1, qC & & $\mathrm{H}-1, \mathrm{H}_{2}-7, \mathrm{H}_{2}-10$ \\
\hline 6 & $83.4, \mathrm{qC}$ & & $\mathrm{H}_{2}-10$ \\
\hline 7 & $45.5, \mathrm{CH}_{2}$ & $\begin{array}{c}3.63(\mathrm{~m}) \\
3.41(\mathrm{ddd}, 12.8,8.5,2.5)\end{array}$ & $\mathrm{H}-3, \mathrm{H}_{2}-9$ \\
\hline 8 & $22.1, \mathrm{CH}_{2}$ & $1.98(\mathrm{~m}), 1.71(\mathrm{~m})$ & $\mathrm{H}_{2}-7$ \\
\hline 9 & $28.7, \mathrm{CH}_{2}$ & $2.17(\mathrm{~m}), 1.83(\mathrm{~m})$ & $\mathrm{H}-3, \mathrm{H}_{2}-8$ \\
\hline 10 & $47.8, \mathrm{CH}_{2}$ & $\begin{array}{l}3.14(\mathrm{~d}, 13.6) \\
3.05(\mathrm{~d}, 13.6)\end{array}$ & $\mathrm{H}-12 / \mathrm{H}-16$ \\
\hline 11 & 133.1, qC & & $\mathrm{H}_{2}-10, \mathrm{H}-12 / \mathrm{H}-16, \mathrm{H}-13 / \mathrm{H}-15$ \\
\hline 12 & $130.6, \mathrm{CH}$ & $7.29(\mathrm{~m})$ & $\mathrm{H}-14$ \\
\hline 13 & $129.4, \mathrm{CH}$ & $7.40(\mathrm{~m})$ & $\mathrm{H}-14$ \\
\hline 14 & $128.1, \mathrm{CH}$ & $7.30(\mathrm{~m})$ & H-12/H-16, H-13/H-15 \\
\hline 15 & $129.4, \mathrm{CH}$ & $7.40(\mathrm{~m})$ & $\mathrm{H}-14$ \\
\hline 16 & $130.6, \mathrm{CH}$ & $7.29(\mathrm{~m})$ & $\mathrm{H}-14$ \\
\hline $\mathrm{OH}$ & & 4.36 (brs) & \\
\hline
\end{tabular}

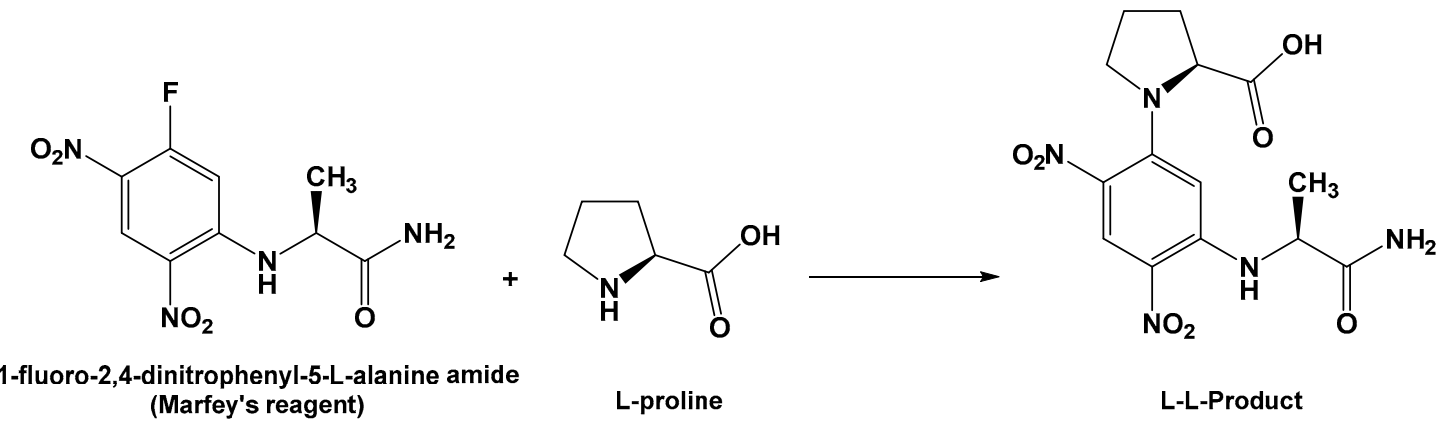

Scheme 2. Reaction of FDAA with the hydrolytic product of compound 2 (L-proline).

Compounds 3 and 4 were assigned as cyclo(D-Pro-L-Phe) \{cyclo(R-Pro-S-Phe)\} (3) [18] and cyclo( $R$-Pro- $R$-Phe) (4) by interpretation of their NMR (Figures S11-S20) and HRMS data. 


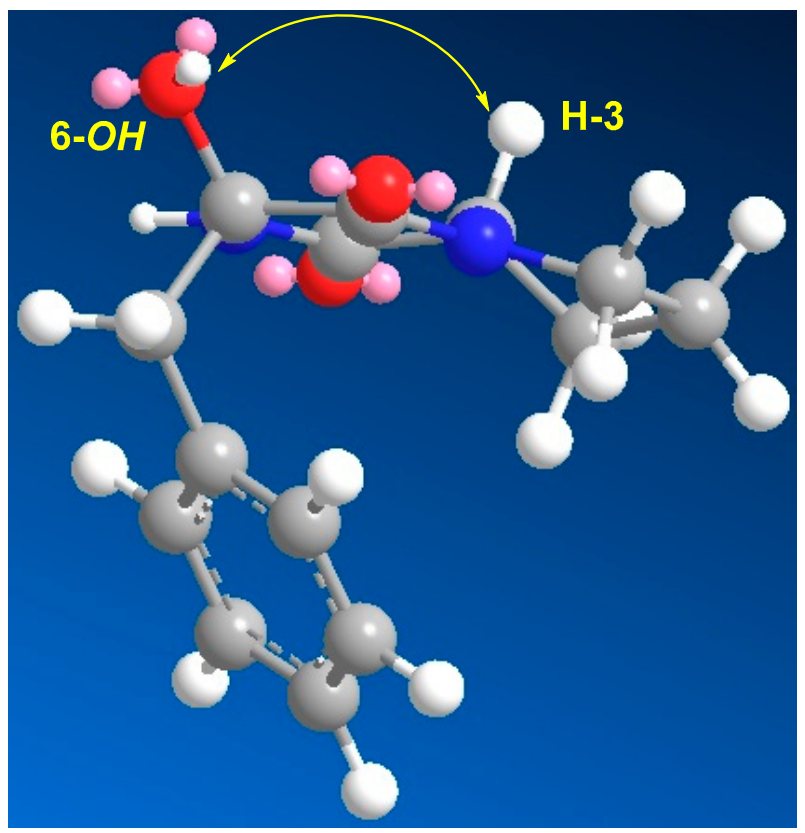

Figure 3. MM2 energy-minimized drawing of $\mathbf{2}$ showing an important NOE correlation.

\subsection{Biological Activities of Compounds 1-4}

Compounds 2-4 were evaluated for their cytotoxic and antiproliferative activities against colorectal carcinoma (HCT 116), hepatocellular carcinoma (HepG2), and breast cancer (MCF-7) using a sulforhodamine assay, as previously described [23]. Compounds 2 and 3 showed significant activity against HCT-116, with $\mathrm{IC}_{50}$ of 23.0 and $38.9 \mu \mathrm{M}$, while compound 4 was weakly active against this cell line. Compounds 3 and 4 were weakly active against MCF-7, with $\mathrm{IC}_{50}$ of 102 and $104 \mu \mathrm{M}$, respectively. Finally, none of the compounds showed activity against HepG2 $(\geq 50 \mu \mathrm{M})$.

In addition, 2-4 were evaluated for their antimicrobial activity against several microbes: S. aureus, Vibrio anguillarum, and C. albicans. Compounds $\mathbf{2}-\mathbf{4}$ showed significant activity against $V$. anguillarum, with inhibition zones of 20, 24, and $25 \mathrm{~mm}$, respectively. Similarly, compounds $\mathbf{2}-\mathbf{4}$ showed moderate activity against both $S$. aureus and C. albicans, with inhibition zones between 10 and $19 \mathrm{~mm}$ (Table 3).

Table 3. Cytotoxic and antimicrobial activities of compounds 2-4.

\begin{tabular}{|c|c|c|c|c|c|c|}
\hline \multirow{2}{*}{ Compound } & \multicolumn{3}{|c|}{$\mathrm{IC}_{50}(\mu \mathrm{M})$} & \multicolumn{3}{|c|}{ Inhibition Zone (mm)@100 $\mu \mathrm{g} /$ disc } \\
\hline & HCT-116 & HepG2 & MCF-7 & S. aureus & V. anguillarum & C. albicans \\
\hline 2 & 23.0 & $\geq 50$ & $\geq 50$ & 19 & 20 & 10 \\
\hline 3 & 38.9 & $\geq 50$ & 102.0 & 14 & 24 & 11 \\
\hline 4 & 94.0 & $\geq 50$ & 114.0 & 16 & 25 & 15 \\
\hline Doxorubicin $^{a}$ & 0.789 & 0.621 & 0.415 & & & \\
\hline Ciprofloxacin $^{b}$ & & & & 22 & 26 & \\
\hline Ketoconazole $^{\mathrm{c}}$ & & & & & & 30 \\
\hline
\end{tabular}

${ }^{\mathrm{a}}$ Positive cytotoxic control; ${ }^{\mathrm{b}}$ positive antibacterial control (5 $\left.\mu \mathrm{g} / \mathrm{disc}\right) ;{ }^{\mathrm{c}}$ positive antifungal control (50 $\left.\mu \mathrm{g} / \mathrm{disc}\right)$.

The results in Table 3 clearly show that compounds $\mathbf{2} \mathbf{- 4}$ were selective against HCT-116 without any activity against HepG2. In comparison to 3 and 4, the hydroxylation of C-6 (in 2) potentiated the cytotoxic activity against HCT-116. In the antimicrobial screen, $\mathbf{2 - 4}$ were almost identically active against $S$. aureus and C. albicans, suggesting no effect for the $\mathrm{OH}$ at $\mathrm{C}-6$. In addition, $\mathbf{2}$ and $\mathbf{3}$ were more active than 2 against $V$. anguillarum and showed similar activity to the positive control ciprofloxacin. 


\section{Materials and Methods}

\subsection{General Experimental Procedures}

One- and two-dimensional NMR spectra (chemical shifts in ppm, coupling constants in Hz) were recorded on Bruker Avance DRX 600 MHz (Bruker, Rheinstetten, Germany) and Bruker Ascend ${ }^{\mathrm{TM}} 850$ (850 MHz) (Bruker BioSpin, Billerica, MA, USA) spectrometers using $\mathrm{CDCl}_{3}$ as solvent. NMR spectra were referenced to the residual protonated solvent signals $\left(\mathrm{CHCl}_{3}: 7.26 \mathrm{ppm}\right.$ for ${ }^{1} \mathrm{H}$ and $\left.77.0 \mathrm{ppm}\right)$. Positive ion HRESIMS data were obtained with a Micromass Q-ToF equipped with leucine enkephalin lockspray, using $m / z 556.2771(\mathrm{M}+\mathrm{H})^{+}$as a reference mass. For column chromatography, silica gel (Merck, 70-230 mesh ASTM, Sigma-Aldrich, Darmstadt, Germany) and Sephadex LH-20 (0.25-0.1 mm, Pharmacia, Piscataway, NJ, USA) were used. Precoated silica gel 60 F-254 plates (Merck) were used for TLC. HPLC purifications were performed on a semipreparative HPLC column (RP18, $5 \mu$, ARII Cosmosil, $250 \times 10 \mathrm{~mm}$, Waters, Nacalai, Inc., San Diego, CA, USA).

\subsection{Biological Materials}

The marine-derived fungus Penicillium sp. was isolated from the Red Sea tunicate Didemnum sp., and the fungus was identified as previously described [13].

\subsection{Culture Condition and Extraction}

Large-scale culture of the fungus Penicillium sp. was carried out in 20 flasks (each 2 L). Each flask contained $500 \mathrm{~mL}$ of Sabouraud Dextrose (HiMedia Laboratories, Vadhani Ind. Est., LBS Marg, Mumbai, India) Broth (SDB) liquid medium. The prepared liquid cultures were shaken on an orbital shaker at $28^{\circ} \mathrm{C}$ continuously for 14 days. After 2 weeks of shaking and incubation, the cultures were filtered using clean gauze to separate the formed fungal mycelia from the broth. The culture broth from each flask was extracted with EtOAc $(3 \times 300 \mathrm{~mL})$. The mycelia formed during the shaking were lyophilized and extracted with $\mathrm{MeOH}$. The ethyl acetate and methanolic extracts were combined and evaporated under vacuum, and the resulting extracts were used for fractionation and purification of the compounds.

\subsection{Isolation and Purification of Compounds 1-4}

The combined extracts of the broth and mycelia $(0.76 \mathrm{~g})$ were flash chromatographed on reverse-phase $\mathrm{SiO}_{2}$ using $\mathrm{H}_{2} \mathrm{O}-\mathrm{MeOH}$ gradients, giving 6 subfractions (A-F). Fraction $\mathrm{B}(120 \mathrm{mg})$, eluted with $25 \% \mathrm{MeOH}$ in $\mathrm{H}_{2} \mathrm{O}$, was fractionated on Sephadex $\mathrm{LH}-20$ column using $\mathrm{MeOH}$ as eluent, giving 6 main subfractions (B1-B6). Fraction B3 (56 mg) was purified on C18 HPLC column using 50\% $\mathrm{CH}_{3} \mathrm{CN}$ to give compounds $3(5.5 \mathrm{mg})$ and $4(3.5 \mathrm{mg})$. Similarly, subfraction $\mathrm{B} 4(30 \mathrm{mg})$ was purified on C18 HPLC column using $45 \% \mathrm{CH}_{3} \mathrm{CN}$ to give compounds $\mathbf{1}(2.7 \mathrm{mg}$ ) and $\mathbf{2}$ (2.3 $\mathrm{mg})$.

\subsection{Determination of Configuration of the Amino Acids in $\mathbf{1}$ and $\mathbf{2}$}

About $0.5 \mathrm{mg}$ each of compounds 1 and 2 was heated separately in $1 \mathrm{~mL}$ of $6 \mathrm{~N} \mathrm{HCl}$ at $100{ }^{\circ} \mathrm{C}$ for $16 \mathrm{~h}$, followed by removal of the excess $\mathrm{HCl}$ under vacuum. To each dry hydrolysate, $200 \mu \mathrm{L}$ of $1 \%$ solution of FDAA [21] in acetone and $40 \mu \mathrm{L}$ of $1.0 \mathrm{M} \mathrm{NaHCO}_{3}$ were added. The reaction mixture was heated at $45^{\circ} \mathrm{C}$ for $1.5 \mathrm{~h}$, cooled, and acidified with $20 \mu \mathrm{L}$ of $2.0 \mathrm{M} \mathrm{HCl}$. Similarly, standard amino acids (D and L) of leucine and proline were derivatized separately. The derivatized standard amino acids and hydrolysates of 1 and 2 were subjected to HPLC on Nova-Pak C18 reverse-phase column $(150 \times 3.9 \mathrm{~mm}$ i.d., $4 \mathrm{~mm}$ particle size; Waters, Milford, MA, USA) using the following gradient program. Solvent A was a $50 \mathrm{mM}$ triethylamine-phosphate buffer ( $\mathrm{pH} 3.5)$ containing $25 \%(v / v) \mathrm{MeOH}$, and solvent B was the same buffer containing $70 \% \mathrm{MeOH}$. The mobile phase was a linear gradient from 0 to $100 \%$ $\mathrm{B}(100$ to $0 \% \mathrm{~A})$ in $40 \mathrm{~min}$, at a flow rate of $0.65 \mathrm{~mL} / \mathrm{min}$ at $25^{\circ} \mathrm{C}$. The eluted peaks were monitored at $340 \mathrm{~nm}$. The retention times for FDAA derivatives of standards and compounds $\mathbf{1}$ and 2 were 
as follows: (L)-leucine ( $t_{\mathrm{R}} 27.2 \mathrm{~min}$ ), (D)-leucine ( $\left.t_{\mathrm{R}} 36.0 \mathrm{~min}\right)$, (L)-proline ( $\left.t_{\mathrm{R}} 15.4 \mathrm{~min}\right)$, (D)-proline $\left(t_{\mathrm{R}} 19.1 \mathrm{~min}\right)$, compound 1 ( $\left.t_{\mathrm{R}} 27.2 \mathrm{~min}\right)$, and compound $2\left(t_{\mathrm{R}} 15.4 \mathrm{~min}\right)$.

Penicillatide $A$ (1): White amorphous powder; $(\alpha)_{\mathrm{D}}=-22^{\circ}(c 0.05, \mathrm{MeOH}) ; \mathrm{NMR}$ data (Table 1); HRESIMS $m / z 227.1395$ (calcd for $\mathrm{C}_{11} \mathrm{H}_{19} \mathrm{~N}_{2} \mathrm{O}_{3},(\mathrm{M}+\mathrm{H})^{+}, 227.1396$ ).

Penicillatide $B$ (2): White amorphous powder; $(\alpha)_{D}=85^{\circ}(c 0.08, \mathrm{MeOH})$; NMR data (Table 2); HRESIMS $m / z 261.1240$ (calcd for $\mathrm{C}_{14} \mathrm{H}_{17} \mathrm{~N}_{2} \mathrm{O}_{3},(\mathrm{M}+\mathrm{H})^{+}, 261.1239$ ).

\subsection{Biological Activities of the Compounds}

\subsubsection{Evaluation of the Cytotoxic Activities of the Compounds}

The cytotoxicity of compounds $\mathbf{2 - 4}$ against 3 tumorous cell lines-colorectal carcinoma, breast cancer, and hepatocellular carcinoma-were evaluated using sulforhodamine assay [23]. Briefly, before adding the compounds, the cells were grown in 96-well plates for $24 \mathrm{~h}$. After adding the compounds, incubation of the cells was carried out for another $48 \mathrm{~h}$. The $\mathrm{IC}_{50}$ values of the compounds were obtained from the log dose-response curve. The reported $\mathrm{IC}_{50}$ values were obtained from the means of 3 experiments.

\subsubsection{Antibacterial Evaluation of the Compounds}

A disc diffusion assay was used to determine the antimicrobial activity of the compounds [24] with replication $(n=3)$. Staphylococcus aureus, Vibrio anguillarum, and Candida albicans served as target models for bacteria and fungi. A total of $100 \mu \mathrm{g}$ of each compound was loaded onto 6-mm sterile circular filter-paper discs. The paper discs were left to air-dry. The dried paper discs were placed onto nutrient agar plates that had already been inoculated with a lawn of target microorganisms. After $24 \mathrm{~h}$ of incubation, the antimicrobial activity of the compounds was calculated.

\section{Conclusions}

Investigation of the marine-derived fungus Penicillium sp. gave two new compounds, penicillatides A and $\mathrm{B}(\mathbf{1}$ and $\mathbf{2})$, together with the known compounds cyclo(R-Pro-S-Phe) (3) and cyclo( $R$-Pro- $R$-Phe) (4). The structures of 1-4 were assigned by interpretation of their spectroscopic data by NMR and high-resolution mass spectroscopy (HRMS). Compounds 2 and $\mathbf{3}$ displayed significant and selective activity against HCT-116, with $\mathrm{IC}_{50}$ of 6.0 and $9.57 \mu \mathrm{g} / \mathrm{mL}$, respectively, while they were inactive against HepG2 and MCF-7. These results suggest a selective effect of $\mathbf{2}$ and $\mathbf{3}$ against HCT-116. Also, 2-4 showed potent antimicrobial activity against $V$. anguillarum, with inhibition zones of 20, 24, and $25 \mathrm{~mm}$, respectively. On the other hand, 2-4 were moderately active against $S$. aureus and C. albicans.

Supplementary Materials: Supplementary materials are available online. Figures S1-S20 (1D and 2D NMR spectra of compounds 1-4).

Acknowledgments: This project was funded by the Deanship of Scientific Research (DSR) at King Abdulaziz University, Jeddah, Kingdom of Saudi Arabia, under grant number (G-232-166-37). The authors therefore acknowledge and thank DSR for technical and financial support.

Author Contributions: D.T.A.Y. designed the experiments; D.T.A.Y. and A.M.A. performed the experiments; D.T.A.Y. and A.M.A. analyzed the data; D.T.A.Y. wrote and edited the manuscript.

Conflicts of Interest: The authors declare no conflict of interest.

\section{References}

1. Rateb, M.E.; Ebel, R. Secondary metabolites of fungi from marine habitats. Nat. Prod. Rep. 2011, $28,290-344$. [CrossRef] [PubMed]

2. Blunt, J.W.; Copp, B.R.; Keyzers, R.A.; Munro, M.H.; Prinsep, M.R. Marine natural products. Nat. Prod. Rep. 2017, 34, 235-294. [CrossRef] [PubMed]

3. Wang, Y.-T.; Xue, Y.-R.; Liu, C.-H. A brief review of bioactive metabolites derived from deep-sea fungi. Mar. Drugs 2015, 13, 4594-4616. [CrossRef] [PubMed] 
4. Imhoff, J.F. Natural products from marine fungi-still an underrepresented resource. Mar. Drugs 2016, 14, 19. [CrossRef] [PubMed]

5. Nicoletti, R.; Trincone, A. Bioactive compounds produced by strains of Penicillium and Talaromyces of marine origin. Mar. Drugs 2016, 14, 37. [CrossRef] [PubMed]

6. Huang, R.M.; Zhou, X.F.; Xu, T.H.; Yang, X.W.; Liu, Y.H. Diketopiperazines from marine organisms. Chem. Biodivers. 2010, 7, 2809-2829. [CrossRef] [PubMed]

7. Huang, R.-M.; Yi, X.-X.; Zhou, Y.; Su, X.; Peng, Y.; Gao, C.-H. An update on 2,5-diketopiperazines from marine organisms. Mar. Drugs 2014, 12, 6213-6235. [CrossRef] [PubMed]

8. Borthwick, A.D. 2,5-Diketopiperazines: Synthesis, reactions, medicinal chemistry, and bioactive natural products. Chem. Rev. 2012, 112, 3641-3716. [CrossRef] [PubMed]

9. Yurchenko, A.; Smetanina, O.; Ivanets, E.; Kalinovsky, A.; Khudyakova, Y.; Kirichuk, N.; Popov, R.; Bokemeyer, C.; von Amsberg, G.; Chingizova, E.; et al. Pretrichodermamides D-F from a marine algicolous fungus Penicillium sp. KMM 4672. Mar. Drugs 2016, 14, 122. [CrossRef] [PubMed]

10. Park, H.B.; Kim, Y.-J.; Park, J.-S.; Yang, H.O.; Lee, K.R.; Kwon, H.C. Glionitrin B, a cancer invasion inhibitory diketopiperazine produced by microbial coculture. J. Nat. Prod. 2011, 74, 2309-2312. [CrossRef] [PubMed]

11. Meng, L.-H.; Zhang, P.; Li, X.-M.; Wang, B.-G. Penicibrocazines A-E, five new sulfide diketopiperazines from the marine-derived endophytic fungus Penicillium brocae. Mar. Drugs 2015, 13, 276-287. [CrossRef] [PubMed]

12. Li, Y.; Li, X.; Kim, S.-K.; Kang, J.S.; Choi, H.D.; Rho, J.R.; Son, B.W. Golmaenone, a new diketopiperazine alkaloid from the marine-derived fungus Aspergillus sp. Chem. Pharm. Bull. 2004, 52, 375-376. [CrossRef] [PubMed]

13. Shaala, L.A.; Youssef, D.T.A. Identification and bioactivity of compounds from the fungus Penicillium sp. CYE-87 isolated from a marine tunicate. Mar. Drugs 2015, 13, 1698-1709. [CrossRef] [PubMed]

14. Murshid, S.S.A.; Badr, J.M.; Youssef, D.T.A. Penicillosides A and B: New cerebrosides from the marine-derived fungus Penicillium species. Rev. Bras. Farmacogn. 2016, 26, 29-33. [CrossRef]

15. Asiry, I.A.M.; Badr, J.M.; Youssef, D.T.A. Penicillivinacine, antimigratory diketopiperazine alkaloid from the marine-derived fungus Penicillium vinaceum. Phytochem. Lett. 2015, 13, 53-58. [CrossRef]

16. Mourshid, S.A.; Badr, J.M.; Risinger, A.L.; Mooberry, S.L.; Youssef, D.T.A. Penicilloitins A and B, new antimicrobial fatty acid esters from a marine endophytic Penicillium species. Z. Naturforsch. C 2016, 71, 387-392. [CrossRef] [PubMed]

17. Shaala, L.A.; Youssef, D.T.A.; Badr, J.M.; Harakeh, S.M. Bioactive 2(1H)-pyrazinones and diketopiperazine alkaloids from a tunicate-derived actinomycete Streptomyces sp. Molecules 2016, 21, 1116. [CrossRef] [PubMed]

18. Adamczeski, M.; Reed, A.R.; Crews, P. New and known diketopiperazines from the Caribbean sponge, Calyx Cf. podatypa. J. Nat. Prod. 1995, 58, 201-208. [CrossRef] [PubMed]

19. Wang, G.; Dai, S.; Chen, M.; Wu, H.; Xie, L.; Luo, X.; Li, X. Two diketopiperazine cyclo(pro-phe) isomers from marine bacteria Bacillus subtilis sp. 13-2. Chem. Nat. Compd. 2010, 46, 583-585. [CrossRef]

20. Shaala, L.A.; Youssef, D.T.A.; Badr, J.M.; Sulaiman, M.; Khedr, A.; El Sayed, K.A. Bioactive alkaloids from the Red Sea marine Verongid sponge Pseudoceratina arabica. Tetrahedron 2015, 71, 7837-7841. [CrossRef]

21. Marfey, P. Determination of D-amino acids. II. Use of a bifunctional reagent, 1,5-difluoro-2,4-dinitrobenzene. Carlsberg Res. Commun. 1984, 49, 591-596. [CrossRef]

22. Wang, Q.-P.; Zhang, H.-B.; Ning, X.; Hang, H.; Huang, Z.-L.; Song, H.-R.; Wang, X.; Wang, P.G. Microwave-assisted construction of C-hydroxydiketopiperazines using lanthanum(III) triflate. Asian J. Org. Chem. 2015, 4, 132-136. [CrossRef]

23. Vichai, V.; Kirtikara, K. Sulforhodamine B colorimetric assay for cytotoxicity screening. Nat. Protoc. 2006, 1, 1112-1116. [CrossRef] [PubMed]

24. Kiehlbauch, J.A.; Hannett, G.E.; Salfinger, M.; Archinal, W.; Monserrat, C.; Carlyn, C. Use of the National Committee for Clinical Laboratory Standards Guidelines for Disk Diffusion Susceptibility Testing in New York State Laboratories. J. Clin. Microbiol. 2000, 38, 3341-3348. [PubMed]

Sample Availability: Samples of the compounds are not available from the authors. 